to requests from scientists for support. More central planning of university-based research also seems to be implied by the decision to establish a special directorate to orchestrate the contribution that universites can make in information technology.

Financial restraints meant that last year SERC supported fewer studentships and advanced course studentships. The number offered in 1982 was 3,178 , compared with 3,600 in 1980. Another significant policy change has been agreed in the way SERC will decide what postgraduate studentships to support. Responsibility is to be devolved to the council's separate subject boards; already the Engineering Board has decided to increase the level of advanced course training that it provides.

In future years there may be an even more difficult partitioning of the science budget to be made, as restructuring costs and capital expenditure within the Agricultural and Food Research Council and the Natural Environmental Research Council press against the aspirations of SERC. Professor Kingman said last week that any diversion of funds away from SERC to meet costs within other councils would amount to "fining the efficient".

Tim Beardsley

Israeli development

\section{To stand alone or deal?}

\section{Rehovot}

ISRAEL'S science-based industry was responsible for the export of more than $\$ 1,000$ million worth of locally-developed products last year, but as this sector grows ever more important, so does the question of its future development. Specifically, policy-makers are trying to decide whether Israel should try to go it alone in the expansion of its science-based industry, or whether emphasis should be put on persuading high-tech companies to set up subsidiaries in this country.

Scitex, with headquarters on the outskirts of Tel Aviv, is one example of what can be accomplished by a purely Israeli high-tech company. After a brief stint on military-related projects, Scitex turned to the development and manufacture of interactive systems for use in graphic arts, mapping and computer-aided design and manufacture.

In the absence of a domestic market for its "gadgets", which sell at $\$ 500,000$ and up, Scitex must sell overseas, and it manages to do so very successfully despite competition from West Germany and Britain. Time magazine, for example, uses Scitex equipment to computerize the makeup of its pages.

Executive vice president Arthur Low said the company has learned to exploit the skills of Israel's scientists and technologists, who contribute more to the country by working for Scitex, he adds, than they would by " providing the missing piece in a puzzle" whose parameters are defined overseas. Moreover, once such a foreign company had made what use it could of Israeli talent, "it might well move on if it found more attractive conditiions elsewhere". Scitex serves instead as the home base for subsidiary companies in the United States, Western Europe and Japan. At any time, one-third of its Israeli personnel are working overseas, gaining valuable experience of potential markets in the process.

Another important Israeli-based enterprise is Ormat Turbines Ltd in Yavne, south of Tel Aviv. Its turbines, which can run on almost any source of heat, are used to power installations in inaccessible its technology to produce electricity from geothermal wells in the United States and solar ponds around the Dead Sea.

Encouraged by his own experience, Ormat's founder, Mr Yehuda Bronicki, argues that Israeli companies are capable of turning out sophisticated products that can compete with those of high-tech enterprises anywhere in the world. But relative isolation from major markets means that they must make extra efforts to keep in touch with the needs of their customers. This is why Ormat, like Scitex, has established subsidiaries abroad and regularly sends its research staff on overseas tours of duty.

Like high-tech companies elsewhere, Israeli enterprises devote a significant percentage of their income to research and development - in 1982,15 per cent of $\$ 15$ million at Ormat and 15 per cent of $\$ 50$ million at Scitex. In addition, such companies receive money from the office of Professor Aryeh Lavie, Chief Scientist of the Ministry of Industry and Commerce.

While Israeli-based high-tech companies are flourishing, so too are local branches of overseas companies. Thus Intel, which eleven years ago opened a semiconductor design centre in Haifa, has now embarked upon a $\$ 130$ million programme to build a wafer fabrication plant in Jerusalem, which will employ 600 people from mid1984. The Israeli subsidiary of another US corporation, Motorola, has during the past two decades increased production from $\$ 500,000$ in 1964 to $\$ 65$ million in 1982 . Moreover, 42 per cent of its exports (worth $\$ 30$ million in 1982) consisted of products developed in Israel.

Eliezer Livnat, of Motorola-Israel, offers the experience of his company as proof that "links with a multinational firm development work by its local subsidiary"'. $\mathrm{He}$ adds that access to the sophisticated technology of an overseas enterprise has helped, especially by providing a readymade worldwide marketing network, and argues that an overseas company is unlikely mountain tops and deserts. Ormat has used do not preclude innovative research and

\section{Huge drug damages}

Washington

A FEDERAL jury in Georgia has ordered Eli Lilly \& Co. to pay $\$ 6$ million in punitive damages for the death of a woman who took the anti-inflammatory drug Oraflex (benoxaprofen). The drug was ordered to be taken off the market in Britain, where it was sold under the name Opren, in August 1982 after reports of 61 deaths among users of the drug (see Nature 298, 597; 1982). On the same day, Lilly suspended sales worldwide.

The damages were the largest dollar amount ever awarded in a drug liability case. Lilly officials said they would file an immediate appeal.

Even before the drug was taken off the market, it had become the centre of a controversy about Lilly's heavy promotion of the product and its failure to report to the US Food and Drug Administration while US approval was pending last spring - about deaths among users elsewhere in the world.

The Georgia verdict was the first of more than 100 suits pending against Lilly in connection with Oraflex. Many of those cases involve adverse reactions other than death. One earlier case in West Germany was found in Lilly's favour last month.

Stephen Budiansky

to close down its Israeli operation so long as it remains efficient and competitive.

Some foreign companies have set up special research units in Israel because skilled manpower is considerably cheaper than in most parts of the Western world. Gelman Sciences Inc. of Ann Arbor, Michigan, for example, maintains such a unit, called Membrane Filtration Technology (MFT), at the Kiryat Weizmann science-based industrial park in Rehovot, and its head, Dr Gerald Tanny, believes that this kind of enterprise is ideal for Israel, which has a reservoir of scientific and technological talent but limited production facilities and a dearth of natural resources.

Tanny believes that Israel's research and development should be concentrated in three areas, electron optics, genetic engineering and chemicals. Marketing, in any case, should initially be handled, he says, by overseas companies "because Israel's markets are overseas".

This view is challenged by Sandy Brown, a US-trained engineer in charge of marketing for Omikron, a Kiryat Weizmann company producing pacemakers and working on other artificial implantable organs. He suggests that Israelis should follow the example set by the Japanese in the early 1950s when, in order to penetrate international markets, a large number of companies combined their marketing efforts. "And when Israeli firms get as big as Sony or Mitsubishi", he adds with a wry smile, "they can market on their own".

Nechemia Meyers 